\title{
Ultrasonic disintegration of microalgal biomass and consequent improvement of bioaccessibility/ bioavailability in microbial fermentation
}

Byong-Hun Jeon ${ }^{1 *}$, Jeong-A Choi ${ }^{1}$, Hyun-Chul Kim ${ }^{1,5}$, Jae-Hoon Hwang ${ }^{1}$, Reda Al Abou-Shanab ${ }^{1,2}$, Brian A Dempsey ${ }^{3}$, John M Regan ${ }^{3}$ and Jung Rae Kim ${ }^{4}$

\begin{abstract}
Background: Microalgal biomass contains a high level of carbohydrates which can be biochemically converted to biofuels using state-of-the-art strategies that are almost always needed to employ a robust pretreatment on the biomass for enhanced energy production. In this study, we used an ultrasonic pretreatment to convert microalgal biomass (Scenedesmus obliquus YSW15) into feasible feedstock for microbial fermentation to produce ethanol and hydrogen. The effect of sonication condition was quantitatively evaluated with emphases on the characterization of carbohydrate components in microalgal suspension and on subsequent production of fermentative bioenergy.

Method: Scenedesmus obliquus YSW15 was isolated from the effluent of a municipal wastewater treatment plant. The sonication durations of $0,10,15$, and 60 min were examined under different temperatures at a fixed frequency and acoustic power resulted in morphologically different states of microalgal biomass lysis. Fermentation was performed to evaluate the bioenergy production from the non-sonicated and sonicated algal biomasses after pretreatment stage under both mesophilic $\left(35^{\circ} \mathrm{C}\right)$ and thermophilic $\left(55^{\circ} \mathrm{C}\right)$ conditions.

Results: A 15 min sonication treatment significantly increased the concentration of dissolved carbohydrates $\left(0.12 \mathrm{~g} \mathrm{~g}^{-1}\right)$, which resulted in an increase of hydrogen/ethanol production through microbial fermentation. The bioconvertibility of microalgal biomass sonicated for 15 min or longer was comparable to starch as a control, indicating a high feasibility of using microalgae for fermentative bioenergy production. Increasing the sonication duration resulted in increases in both algal surface hydrophilicity and electrostatic repulsion among algal debris dispersed in aqueous solution. Scanning electron microscope images supported that ruptured algal cell allowed fermentative bacteria to access the inner space of the cell, evidencing an enhanced bioaccessibility. Sonication for 15 min was the best for fermentative bioenergy (hydrogen/ethanol) production from microalga, and the productivity was relatively higher for thermophilic $\left(55^{\circ} \mathrm{C}\right)$ than mesophilic $\left(35^{\circ} \mathrm{C}\right)$ condition.
\end{abstract}

Conclusion: These results demonstrate that more bioavailable carbohydrate components are produced through the ultrasonic degradation of microalgal biomass, and thus the process can provide a high quality source for fermentative bioenergy production.

Keywords: Microalga, Ultrasonication, Cell lysis, Carbohydrate components, Bioenergy

\footnotetext{
* Correspondence: bhjeon@yonsei.ac.kr

${ }^{1}$ Department of Environmental Engineering, Yonsei University, Wonju,

Gangwon-do 220-710, South Korea

Full list of author information is available at the end of the article
} 


\section{Background}

There has been an increasing interest in use of the renewable and sustainable biomass, namely the third generation feedstock for bioenergy production. Microalgae have gained considerable attention as an alternative biofuel feedstock $[1,2]$ as recent discoveries indicate that most algal biomass is exceedingly rich in carbohydrate and oil [3], which can be converted to biofuels using existing technology. Especially high levels of biogas and biofuel can be produced using carbohydrate of algal biomass via fermentation process [4]. Glucose in algal biomass is the most important monosaccharide affecting the fermentative ethanol production that is greatly dependent upon the composition of carbohydrate components in organic substrates. Bioenergy production from biomass generally requires three sequential processes, i.e., hydrolysis, acidification, and bioenergy generation. Numerous studies using algal biomass have reported that hydrolysis is often the rate-limiting step due to rigid cell walls and cytoplasmic membranes that inhibit or delay subsequent biodegradation in the fermentation processes.

Several methods for algal cell disruption have been evaluated including ultrasonication, bead beating, microwave (at $100^{\circ} \mathrm{C}$ ), osmotic shock (with $\mathrm{NaCl}$ ) and autoclaving (at $121^{\circ} \mathrm{C}$ ) with varied results $[5,6]$. Sonication has the advantage of being able to disrupt the cells at relatively low temperatures when compared to microwave and autoclave. In addition, sonication does not require the addition of beads or chemicals, thus decreasing processing cost. Ultrasonication has been commonly used for cell lysis and homogenization, and could be an effective treatment for breaking up the rigid cell envelopes of microalgae [7]. During ultrasonication, sonic waves are transmitted to the microalgal culture. The waves create a series of microbubble cavitations which imparted kinetic energy into the surface of the cells and eventually ruptured the cell walls facilitating the release of carbohydrates and lipids from the cell into the exocellular medium [8]. Acoustic streaming is the other mechanism for using ultrasonication that facilitates the mixing of solution. Such homogenization of algal suspension can improve enzymatic and/or bacterial access to substrates and therefore facilitates the subsequent fermentation process $[9,10]$.

Despite the wide use of algal biomass as a feedstock to produce bioenergy, there are only a few studies that quantitatively determine the compositional distribution of carbohydrate components which affects the productivity of fermentative bioenergy. We previously investigated the feasibility of using ultrasonication as a pretreatment prior to bacterial fermentation of microalgal biomass. Ultrasonication resulted in physical disintegration of microalga cell walls and consequently enhanced fermentative production of hydrogen and ethanol [4]. However, the earlier study did not determine the qualitative and quantitative characteristics of the lysed biochemicals. The main objective of this study therefore was to quantitatively evaluate the performance of sonication on microbial fermentation process and to systematically characterize the biochemical compositions and properties of microalgal biomass before and after the sonication pretreatment in the following ways: (1) investigate the composition of carbohydrate components in both dissolved and solid phases; (2) determine the abiotic conversion of total carbohydrates to the dissolved phase through sonication; (3) measure both surface hydrophobicity and electrical stability of micro-algal cell; and (4) evaluate bioenergy productivity via microbial fermentation of microalgal biomass (compared with soluble starch) under different thermal conditions.

\section{Results and discussion}

\section{Composition and bioavailability of carbohydrate components from algal biomass}

Microalgal suspensions were exposed to four different sonication durations of 0 (non- sonication), 10 (shortterm treatment), 15 and $60 \mathrm{~min}$ (long-term treatment) at $45^{\circ} \mathrm{C}$. No change was found in the concentration of dissolved carbohydrates after 10 min sonication compared to non-sonication (data not shown). A $15 \mathrm{~min}$ sonication treatment increased the dissolved fraction of total carbohydrates from 3\% to 32\%. Further increase of sonication up to $60 \mathrm{~min}$ resulted in an insignificant increase of the dissolved fraction, accounting for $<1 \%$ of total carbohydrates. This result implies that effective algal cell lysis had occurred within 15 min by sonication, resulting in rupture of the cell walls and intracellular materials release to the medium. Ultrasonication of microbes can result in much more hydroxyl groups of carbohydrates and/or lipids on the inner and outer cell surfaces due to extensive cell disintegration and lysis [11]. The hydrophilic nature of saccharide-like substances can also make it possible to increase the solubility of organic materials in culture broth because of the electro-negativity of oxygen atoms in hydroxyl ions [12].

Table 1 shows that total carbohydrates accounted for $37 \%$ of the nonsonicated algal biomass. Microalgae such as Chlorella, Chlamydomonas, Dunaliella, Scendesmus, and Tetraselmis have been shown to accumulate a large amount of carbohydrate ( $>40 \%$ of the dry weight) [13]. Cell wall of the green algae such as Scenedesmus, Chlorella, Monoraphidium, and Ankistrodesmus contains 24-74\% of neutral sugars, $1-24 \%$ uronic acid, $2-16 \%$ proteins, and $0-15 \%$ glucosamine [14]. The major fractions of sugars are either mannose/glucose or rhamnose/galactose [14]. Glucose and mannose were the major constituents among the quantified monosaccharides, and accounted for $66.4 \%$ (which decreased to $60.4 \%$ by a $60 \mathrm{~min}$ sonication) and $21.7 \%$ (which increased to $25.6 \%$ after the sonication) of total monomeric sugars, respectively. The increased 
Table 1 Effect of sonication treatment on composition and bioavailability of total carbohydrate components

\begin{tabular}{|c|c|c|c|c|c|c|}
\hline \multirow[t]{2}{*}{ Sonication time, $\min$} & \multicolumn{2}{|c|}{0} & \multicolumn{2}{|r|}{15} & \multicolumn{2}{|r|}{60} \\
\hline & Non-sonicated & Fermented & Sonicated & Sonicated/fermented & Sonicated & Sonicated/fermented \\
\hline Total carbohydrate, $\mathrm{g} \mathrm{g}^{-1}$ & $0.37(0.01)^{a}$ & 0.22 & $0.37(0.12)$ & 0.08 & $0.39(0.13)$ & 0.09 \\
\hline Glucose (\%) & 66.38 & 31.90 & 63.67 & 8.03 & 60.40 & 7.62 \\
\hline Mannose (\%) & 21.76 & 18.81 & 24.33 & 2.78 & 25.60 & 2.67 \\
\hline Galactose (\%) & 5.94 & 5.68 & 8.66 & 8.04 & 10.22 & 10.12 \\
\hline Glucosamine (\%) & 5.92 & 3.06 & 3.34 & 2.78 & 3.78 & 2.66 \\
\hline
\end{tabular}

${ }^{a}$ The values in the parentheses show the concentrations of dissolved carbohydrates ( $\mathrm{g}$-carbohydrate $\mathrm{g}^{-1}$-biomass).

Sonication pretreatment of algal biomass was conducted at $45^{\circ} \mathrm{C}$ for 15 or $60 \mathrm{~min}$. Both non-sonicated and sonicated algal biomass were mixed with an equivalent volume of fermenting bacteria and subsequently fermented at $35^{\circ} \mathrm{C}$ for 23 days. Other common monomeric dissolved carbohydrates (such as fucose, rhamnose, and galactosamine) were not detected.

portion of mannose might be derived from glucose due to sonication [15,16]. Sonication also resulted in small changes in the concentrations of galactose and glucosamine as minor constituents.

Long-term sonication resulted in large increases in dissolved carbohydrates and in fermentative utilization of the carbohydrates. Table 1 shows that dissolved carbohydrates increased from $1 \%$ of biomass in nonsonicated microalga to $12 \%$ of biomass after $15 \mathrm{~min}$ sonication. A 15 min sonication pretreatment also significantly increased total carbohydrates consumption during the following fermentation stage. The amount of total carbohydrates sharply decreased to $89 \%$ for the first 16 days of fermentation, while extremely small amounts of residual carbohydrates consistently decreased in the fermentor up to 23 days. Fermentation of fresh algal biomass at $35^{\circ} \mathrm{C}$ for 23 days resulted in a decrease in total carbohydrates from $0.37 \mathrm{~g}$-carbohydrate $\mathrm{g}^{-1}$-biomass to 0.22 g-carbohydrate $\mathrm{g}^{-1}$-biomass, while the fermentation after 15 min sonication significantly reduced the total carbohydrates to $0.08 \mathrm{~g}$-carbohydrate $\mathrm{g}^{-1}$-biomass. The improved utilization of carbohydrates by sonication was attributed to both increased dissolved carbohydrate concentrations and increased microbial access to carbohydrates was available on the ruptured cell walls.

\section{Electrical stability and functional property of microalgal cell}

Several previous studies reported that hydrophobic aggregation decreased bioaccessibility of fermenting bacteria to substrate $[17,18]$. The surface charge represented by zeta potential is important for a better understanding on the nature of the particle stability [19], and it has also been well-known that colloidal particles with higher absolute values of the zeta potential tend to be less aggregated due to high electrical repulsion among the particles [20,21]. The $\mathrm{pH}$ of the mixture of microalgal biomass and inoculum (fermenting microbes) ranged from 5.7 to 6.8 at the beginning of fermentation, and the final $\mathrm{pH}$ values after the 23 days of fermentation were nearly identical $(5.5 \pm 0.2)$ in all sets of tested samples. Figure 1 shows that the zeta potential of algal biomass was slightly negative at $\mathrm{pH} 5$, became more negative as the $\mathrm{pH}$ increased to 9 , and was sharply decreased by a 15 min sonication regardless of the initial $\mathrm{pH}$ values. Our result indicates that algal cell became more electrostatically stable in aqueous solution at $\mathrm{pH} 5$ and 9 as a result of sonication treatment for $15 \mathrm{~min}$ or longer due to exposed functional group as well as the release of negatively charged organic constituents upon cell lysis. This result also coincided with a significant increase of the dissolved carbohydrate fraction in the suspension upon sonication [12].

Sonication treatment for up to $10 \mathrm{~min}$ did not significantly changed the algal surface hydrophobicity accounting for $75 \pm 3 \%$, but which was decreased to $54 \pm 2 \%$ or $28 \pm 3 \%$ by a $15 \mathrm{~min}$ or $60 \mathrm{~min}$ sonication, respectively, at $45^{\circ} \mathrm{C}$. It should be noted that almost identical hydrophobicity was observed in sonication of algal biomass at two tested temperatures. The results reveal that algal biomass was significantly hydrophilized by sonication treatment at $45^{\circ} \mathrm{C}$ or higher for $15 \mathrm{~min}$. Chen et al. (2004) showed that sonication changed the molecular structure of organic matter,

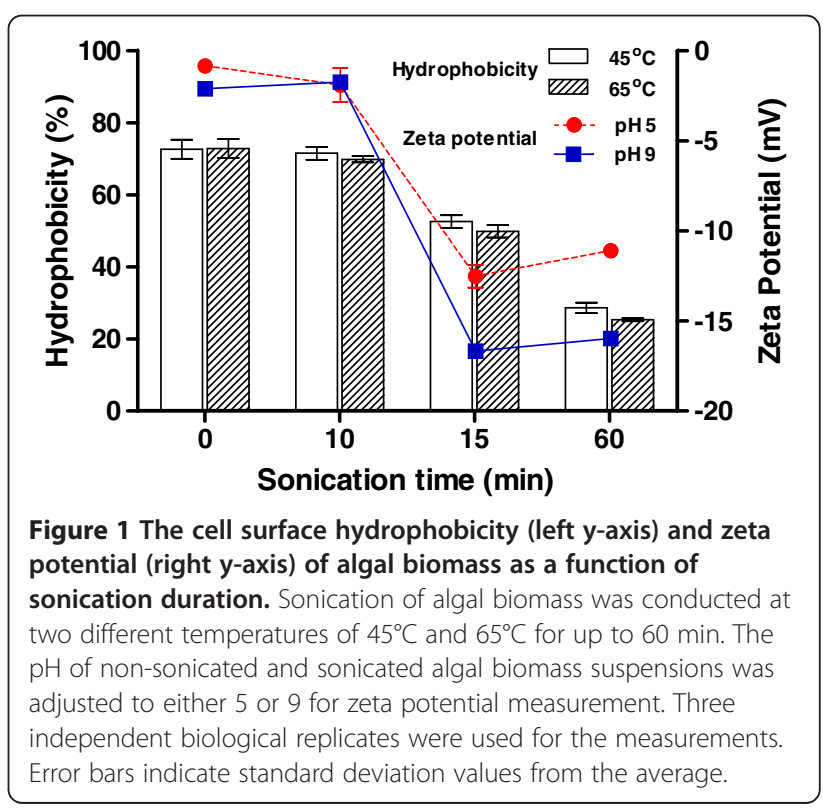


especially resulting in decreases in aromaticity, molecular weight, and specific UV absorbance that has been used as an indicator of organic hydrophobicity [22]. These changes to organic properties were consistent with our observation showing a significant decrease in the surface hydrophobicity of microalga, possibly due to hydroxyl radical production resulting in a substantial degradation of organic compounds and thus an increase in the assimilable organic carbon fraction of the total organic carbon pool [23]. The destruction of algal cell structures during sonication pretreatment also released more algal cell fragment to the aqueous phase, which was observed by increased residual turbidity by $24 \%$. The functionality of organic matter is an important factor in determining how efficient heterotrophic bacteria can assimilate the organic substrates. Numerous studies have demonstrated that heterotrophic microorganisms preferably assimilate hydrophilic organic substrates to a much greater extent than hydrophobic organics $[24,25]$.

Our result showed that the sonication decreased hydrophobicity of cell fragments compared to the control, possibly due to a decrease in the number of conjugated bonds in chain structures [22,26]. Review of the literature demonstrates that algal cells are significantly hydrophilized by ultrasonication [27], which was demonstrated with improved availability of algal biomass as a fermentable substrate for the fermenting bacteria in this study. Hydrophilic functional groups of particle surface also contribute to increasing colloidal stability as shown in zeta potential in this study along with an increase of the specific surface area, resulting in improved bacterial accessibility and metabolic activity $[17,18]$. These previous findings were consistent with our observation showing an increase of carbohydrate consumption in the microbial fermentation of algal biomass after sonication treatment.

\section{Effects of sonication duration and fermenting temperature on bioenergy production}

Figure 2 shows the compositional distribution and concentrations of soluble metabolite product (SMP) after the 23 day fermentation of algae biomass under different thermal conditions $\left(35^{\circ} \mathrm{C}\right.$ and $\left.55^{\circ} \mathrm{C}\right)$. The concentrations of ethanol and volatile fatty acid (VFAs) were increased as the sonication duration was increased to $15 \mathrm{~min}$, while the production of those materials was rarely improved even when the sonication duration was increased up to 60 min regardless of the fermentation temperature. Figure 2 also compares algal biomass (both sonicated and nonsonicated) as a substrate with starch as a control for

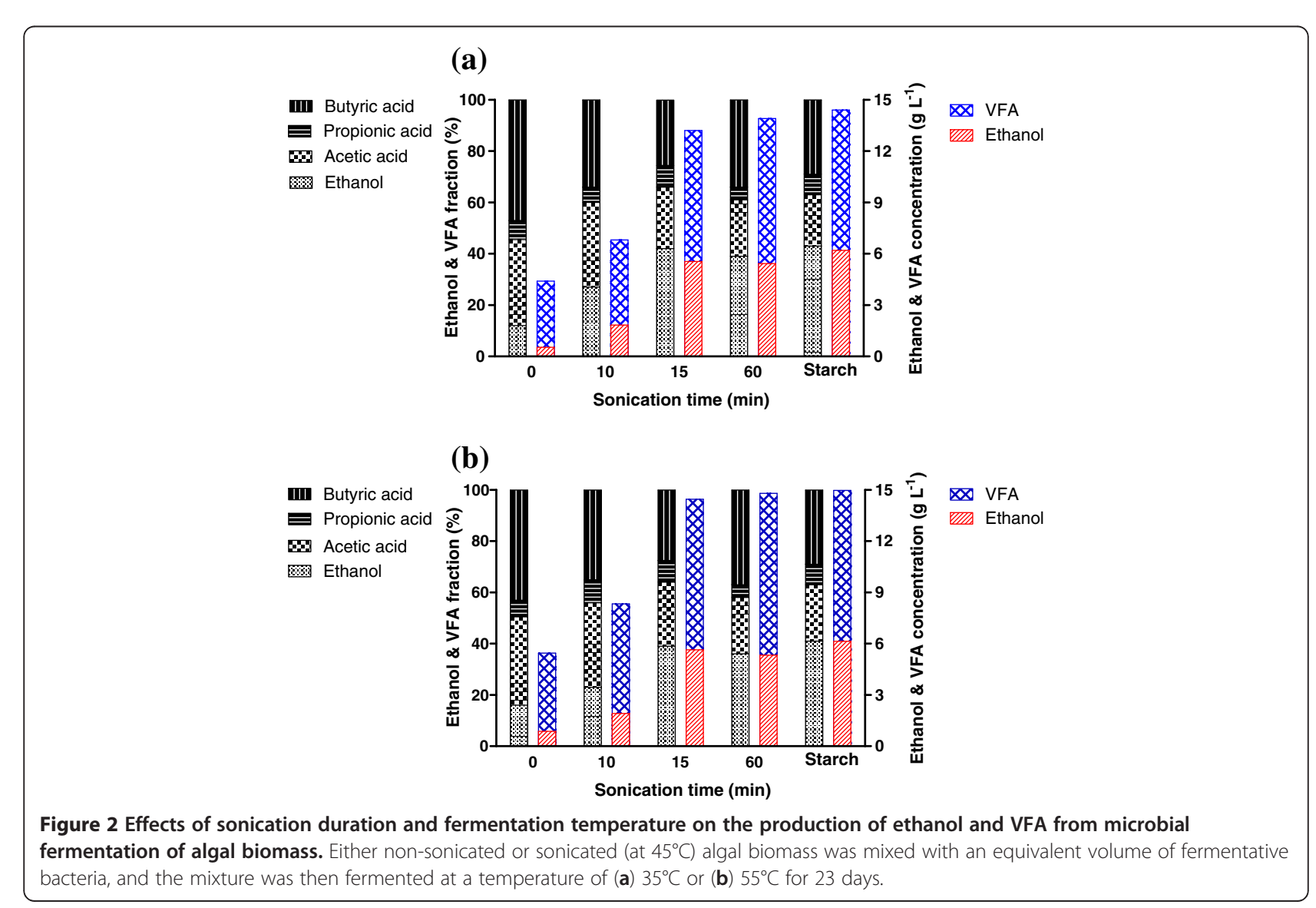


Figure 3 Effects of the ratio of algal biomass to fermentative bacteria ( $A B: F B)$ on the production of hydrogen and ethanol during the 23 day fermentation at a temperature of $35^{\circ} \mathrm{C}$ ( $a$ and $b$ ) or $55^{\circ} \mathrm{C}$ (c and d). The algal biomass was sonicated at $45^{\circ} \mathrm{C}$ for $15 \mathrm{~min}$.

microbial fermentation in terms of the bioenergy productivity. The use of algal biomass sonicated for $15 \mathrm{~min}$ or longer was comparable to soluble starch as a feedstock for the production of ethanol/VFAs throughout the 23 day fermentation period. In case of sonication pretreatment for $15 \mathrm{~min}$ or longer, butyric acid was the dominant form of VFAs followed by acetic acid and propionic acid. Fermentative biofuel production from organic substances results in incomplete decomposition of substrate into organic acids such as acetate and butyrate. Butyrate is more dominant because of its lower Gibbs free energy $(\Delta G=-257.1 \mathrm{~kJ})$ compared to acetate $(\Delta \mathrm{G}=-184.2 \mathrm{~kJ})$ and its production involves enzyme activity [28]. This observation was consistent with previously reported work in which the butyrate type fermentation process was employed $[4,27,29]$. Ethanol has also been reported as the major SMP during anaerobic degradation of saccharide-like substances because monomeric sugars can be utilized easily by heterotrophic microbes (e.g., fermentative bacteria) [30].

The results of microbial fermentations with nonsonicated and sonicated algal biomass are shown in Figure 3 in which cumulative hydrogen and ethanol production are plotted according to time. Production of ethanol resulted in decreased hydrogen production, which was consistent with an earlier report that hydrogen production was decreased when ethanol production was initiated [31]. This was due to a shift of metabolic pathway from butyrate fermentation to ethanol fermentation. The maximum production of hydrogen $\left(\mathrm{H}_{\max }\right)$ via microbial fermentation of algal biomass at $55^{\circ} \mathrm{C}$ was $10 \%$ higher than achieved at $35^{\circ} \mathrm{C}$, but the fermenting thermal conditions rarely affected the energy conversion efficiency $\left(\mathrm{H}_{2}\right.$ yield). Table 2 shows that the maximum hydrogen production rate $\left(\mathrm{R}_{\max }\right)$ was independent of the temperatures between $45^{\circ} \mathrm{C}$ and $65^{\circ} \mathrm{C}$ in ultrasonic pretreatment of algal biomass. As the volumetric ratio of algal biomass to fermentative bacteria ( $\mathrm{AB}: \mathrm{FB})$ was increased from 0.2 to 1.0 , the maximum accumulative hydrogen production increased from 0.72 to $2.51 \mathrm{~L} \mathrm{~L}^{-1}$ and from 0.87 to $2.72 \mathrm{~L} \mathrm{~L}^{-1}$ at two different fermenting temperatures of $35^{\circ} \mathrm{C}$ (mesophilic) and $55^{\circ} \mathrm{C}$ (thermophilic), respectively. This might be attributed to the improved fermentative bacteria activity at the higher organic loading rate under themophilic conditions. The dissolved carbohydrates concentration increased by sonication was also correlated with the increased $\mathrm{H}_{2}$ production, and the remarked production of hydrogen was thus due to improved bioavailability of 
algal biomass for the fermenting bacteria. The $\lambda$ (average lag time) values calculated from Gompertz equation are close to those observed in the experiments. The $\lambda$ value prior to exponential hydrogen production was $11 \mathrm{~h}$ under mesophilic conditions, while thermophilic showed much shorter $\lambda\left(2\right.$ to $3 \mathrm{~h}$ ) and relatively higher $R_{\max }$ (up to $0.3 \mathrm{~L} \mathrm{~L}^{-1} \mathrm{~h}^{-1}$ ) compared to observed for mesophilic. Our observations were consistent with previously reported work in which anaerobic fermentation of glucose increased the production of hydrogen when operating the fermenter with high organic loading rates under thermophilic conditions [29]. Many factors such as substrates, their concentration, $\mathrm{pH}$ and temperature can influence on the fermentative hydrogen production $[32,33]$. Among them, temperature is a key factor because it can affect the activity of hydrogen producing bacteria (HPB) by influencing the activity of essential enzymes such as hydrogenases for fermentative hydrogen production $[34,35]$.

Ethanol production from algal biomass was increased from 0.9 to $5.6 \mathrm{~g} \mathrm{~L}^{-1}$ with increasing the $\mathrm{AB} / \mathrm{FB}$ ratio from 0.2 to 1.0 under mesophilic condition. The highest ethanol production among the experimental variations using algal biomass was comparable to the fermentation of equal amount of carbohydrate in starch (see Table 2 and Figure $3 \mathrm{~b}$ and $\mathrm{d}$ ). Carbohydrates accounting for $37 \%$ of the algal biomass were not only especially beneficial components for heterotrophic bacterial activity, but also a valuable source for fermentative bacteria leading to enhanced energy production.

\section{SEM images of the sonicated alga}

Extensive cell wall damage was observed after a 15 or 60 min sonication which allowed fermentative bacteria to access the inner space of the ruptured algal cell (Figure $4 \mathrm{c}$ and $\mathrm{d}$ ), while an external shape of alga sonicated for $10 \mathrm{~min}$ did not look much different from the intact surface of algal biomass on which fermentative bacteria worked (Figure 4a and b). SEM images clearly show greater accessibility of fermentative bacteria to surface-bound carbohydrates of algal debris after sonication $\geq 15$ min compared to control and $10 \mathrm{~min}$ sonication. Further some of the nucleus materials in the sonicated alga presumably spread outside the cell due to complete cell lysis, coincided with a significant increase in the dissolved fraction of total carbohydrates after sonication for 15 min or longer (Table 1). Therefore the long-term sonication pretreatment resulted in enhanced bioaccessibility and bioavailability of algal biomass, which led to the increases in carbohydrate consumption and subsequent bioenergy (hydrogen/ethanol) production.

\section{Conclusions}

This study has characterized the carbohydrate components in algal suspension upon sonication that could result in significant changes in the physicochemical properties of algal cell and subsequent enhancement of biodegradability/bioaccessibility for microbial fermentation. Sonication pretreatment for $15 \mathrm{~min}$ or longer on algal biomass (S. obliquus YSW15) resulted in a large increase in dissolved carbohydrates (composed mainly of glucose), likely due to release from the cell wall and the

Table 2 Effects of pretreatment temperature and fermentation conditions on hydrogen production from algal biomass sonicated for $15 \mathrm{~min}$ at a given frequency and acoustic power

\begin{tabular}{|c|c|c|c|c|c|c|c|c|c|c|}
\hline $\begin{array}{l}\text { Sonication } \\
\text { temperature }\left({ }^{\circ} \mathrm{C}\right)\end{array}$ & $\begin{array}{l}\text { Fermentation } \\
\text { temperature }\left({ }^{\circ} \mathrm{C}\right)\end{array}$ & $\begin{array}{c}\mathrm{AB} / \mathrm{FB} \\
\text { ratio }(v / v){ }^{a}\end{array}$ & $\mathrm{pH}_{\mathrm{i}}{ }^{\mathrm{b}}$ & $\mathrm{pH}_{\mathrm{f}}{ }^{\mathrm{c}}$ & $\begin{array}{l}\text { Glucose } \\
(g)\end{array}$ & $\begin{array}{l}\text { Lag time, } \\
\lambda(\mathrm{hr})\end{array}$ & $\begin{array}{c}\mathrm{H}_{2} \text { yield } \\
\text { (mol H} \mathrm{mol}^{-1} \text { glucose) }\end{array}$ & $\begin{array}{l}\mathrm{H}_{\max } \mathrm{e} \\
\left(\mathrm{L} \mathrm{L} \mathrm{L}^{-1}\right)\end{array}$ & $\begin{array}{l}f \\
R_{\max } \\
\left(L L^{-1} h^{-1}\right)\end{array}$ & Note \\
\hline \multirow{8}{*}{45} & \multirow{4}{*}{35} & 0.2 & 5.7 & 5.5 & 0.09 & 11 & 1.6 & 0.72 & 0.02 & \\
\hline & & 0.4 & 6.4 & 5.6 & 0.18 & 12 & 1.5 & 1.39 & 0.04 & \\
\hline & & 1.0 & 6.8 & 5.4 & 0.44 & 12 & 1.6 & 2.51 & 0.16 & \\
\hline & & $1.0^{\mathrm{g}}$ & 6.4 & 5.7 & 0.50 & 9 & 1.9 & 2.99 & 0.18 & starch \\
\hline & \multirow{4}{*}{55} & 0.2 & 5.8 & 5.6 & 0.09 & 2 & 1.5 & 0.87 & 0.03 & \\
\hline & & 0.4 & 6.4 & 5.4 & 0.18 & 3 & 1.7 & 1.48 & 0.13 & \\
\hline & & 1.0 & 6.7 & 5.3 & 0.44 & 2 & 1.9 & 2.72 & 0.27 & \\
\hline & & $1.0^{\mathrm{g}}$ & 6.5 & 5.4 & 0.50 & 2 & 1.9 & 3.41 & 0.31 & starch \\
\hline \multirow{6}{*}{65} & \multirow{3}{*}{35} & 0.2 & 5.7 & 5.4 & 0.09 & 12 & 1.6 & 0.88 & 0.03 & \\
\hline & & 0.4 & 6.3 & 5.6 & 0.18 & 11 & 1.8 & 1.36 & 0.06 & \\
\hline & & 1.0 & 6.8 & 5.7 & 0.44 & 11 & 1.8 & 2.94 & 0.15 & \\
\hline & \multirow[t]{3}{*}{55} & 0.2 & 5.9 & 5.4 & 0.09 & 2 & 1.7 & 0.92 & 0.04 & \\
\hline & & 0.4 & 6.2 & 5.6 & 0.18 & 3 & 1.8 & 1.33 & 0.14 & \\
\hline & & 1.0 & 6.6 & 5.6 & 0.44 & 3 & 1.8 & 2.91 & 0.30 & \\
\hline
\end{tabular}

${ }^{\mathrm{a}}$ The volumetric ratio of algal biomass (AB) to fermentative bacteria (FB); ${ }^{\mathrm{b}}$ initial $\mathrm{pH}^{{ }^{\mathrm{c}}}$ final $\mathrm{pH} ;{ }^{\mathrm{d}}$ glucose content in $50 \mathrm{~mL}$ of either algal suspension or liquid starch; ${ }^{e}$ maximum accumulative $\mathrm{H}_{2}$ production; ${ }^{\mathrm{f}}$ maximum $\mathrm{H}_{2}$ production rate; ${ }^{g}$ the volumetric ratio of non-sonicated liquid starch to fermentative bacteria (FB). 

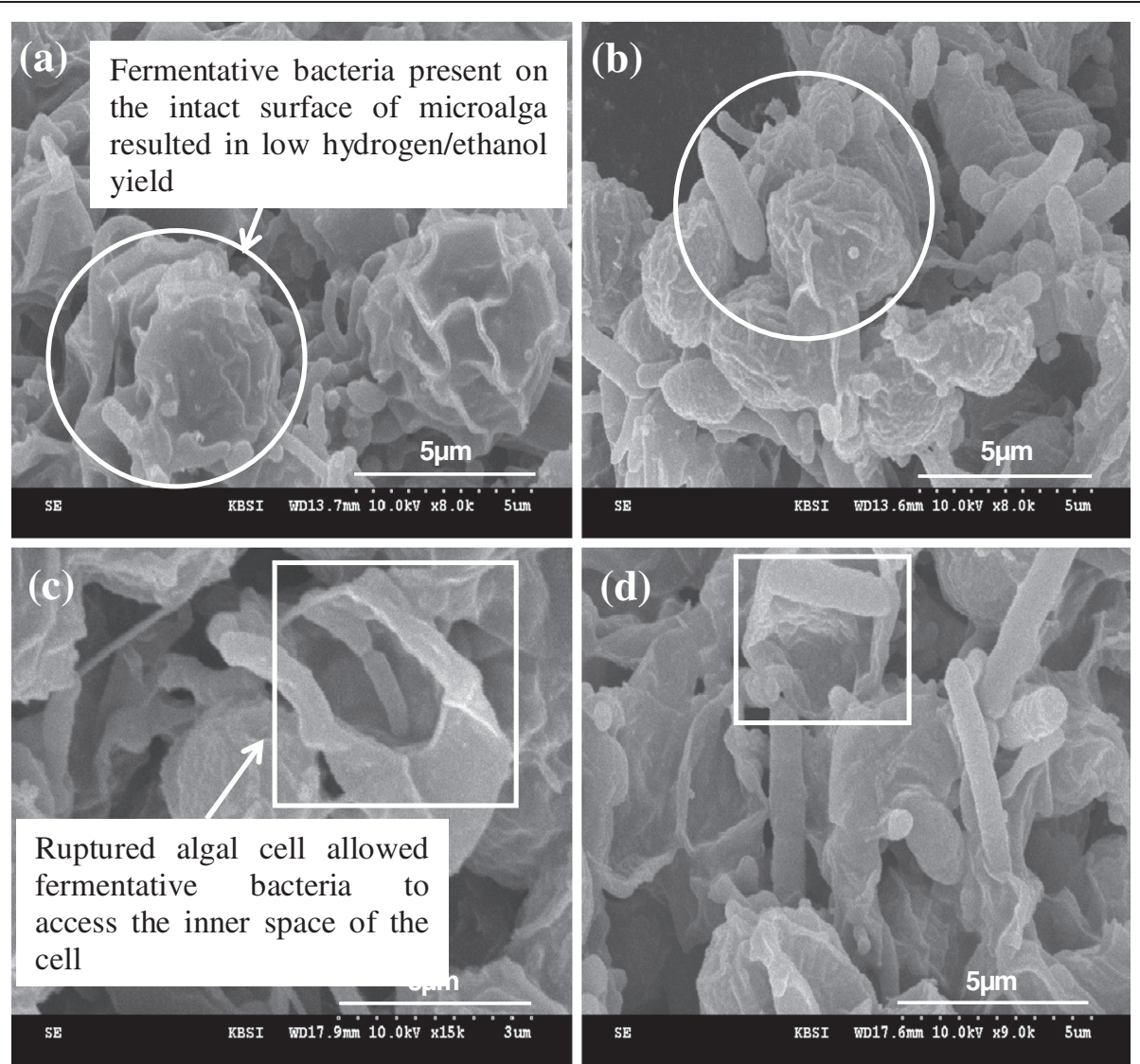

Figure 4 SEM images of fermentative bacteria along with non-sonicated or sonicated algal cells. Non-sonicated algal cells (a and $\mathbf{b}$ ): (a) non- or (b) 10 min sonication. Sonicated algal cells (c and d): (c) $15 \mathrm{~min}$ or (d) $60 \mathrm{~min}$ sonication. The circles indicate fermentative bacteria present on the intact surface of algae, while the squares show ruptured algal cells allowed fermentative bacteria to access the inner space of the algal cells, resulting in high hydrogen/ethanol production.

periplasm. Sonication enhanced fermentative bioenergy (hydrogen/ethanol) production, and resulted in comparable bioenergy production as compared to using soluble starch. Algal surface hydrophobicity was substantially decreased and electrostatic repulsion among algal debris dispersed in aqueous solution was significantly increased by a 15 min sonication treatment, which provided more facile access of the fermentative bacteria to algal biomass for assimilating carbohydrates of the algal cell fragments. A substantial uptake of the carbohydrate by the fermenting bacteria occurred during thermophilic fermentation of algal biomass sonicated for $15 \mathrm{~min}$ or longer, coincided with the high bioenergy production (e.g., ethanol $5.6 \mathrm{~g} \mathrm{~L}^{-1}$ and hydrogen $2.5 \mathrm{~mL} \mathrm{~L}^{-1}$ ). The bioenergy productivity increased with increasing the organic substrate loading rate on the microbial fermentation regardless of the thermal conditions examined in this study. The economic evaluation of using the renewable carbon sources for promoting microbial fermentation concurrent with bioenergy production should be further investigated.

\section{Methods}

\section{Cultivation of microalga}

Scenedesmus obliquus YSW15 used in this study was isolated from the effluent of a municipal wastewater treatment plant at Wonju Water Supply and Drainage Center, South Korea [36]. The algal strain was grown in $1 \mathrm{~L}$ Erlenmeyer flask containing 0.5 L Bold Basal Medium (BBM) [37]. The culture was incubated on a rotary shaker (SH-804, Seyoung Scientific) at $27^{\circ} \mathrm{C}$ and $150 \mathrm{rpm}$ under continuous fluorescent illumination with an intensity of $40 \mu \mathrm{mol} \mathrm{m} \mathrm{m}^{-2} \mathrm{~s}^{-1}$ for three weeks.

\section{Ultrasonication}

The harvested microalga biomass $\left(34 \mathrm{mg} \mathrm{mL}^{-1}\right)$ was placed in a glass bottle and sonicated for 10,15 , or $60 \mathrm{~min}$ in a Branson 8510-DTH sonicator (Danbury, Connecticut, USA) at two different temperatures $\left(45\right.$ and $\left.65^{\circ} \mathrm{C}\right)$. The bath-type sonicator was used in this study due to the localized cavitation produced by horn-type sonicators $[38,39]$. The sonication was conducted at a constant frequency of $40 \mathrm{kHz}$ and an output power of $2.2 \mathrm{~kW}$ for 
which the ultrasonic energy was applied in continuous (non-pulsed) mode with constant amplitude of $40 \%$ with specific supplied energy (Es) $70.6 \mathrm{MJ} \mathrm{Kg}^{-1}$.

\section{Anaerobic inoculums}

Seed sludge used in this study was collected from the anaerobic digesters of a municipal wastewater treatment plant (Wonju Water Supply and Drainage Center, Wonju, South Korea). The microbial sludge was heated at $90^{\circ} \mathrm{C}$ for $30 \mathrm{~min}$ to inactivate methanogenic bacteria and to enhance the activity of $\mathrm{H}_{2}$-producing bacteria (HPB). The HPB was acclimatized to a synthetic medium in an anaerobic chemostat reactor for 1 month [40]. The medium was prepared daily and stored in a substrate reservoir maintained at $4^{\circ} \mathrm{C}$. An anaerobic reactor ( $2 \mathrm{~L}$ of capacity with $1 \mathrm{~L}$ working volume) was filled with a mixture of pretreated sludge and synthetic medium, and operated with a hydraulic retention time of $12 \mathrm{~h}$ at $35^{\circ} \mathrm{C}$.

\section{Fermentation of microalgae biomass}

Microbial fermentation was performed to evaluate the bioenergy production from the non-sonicated and sonicated algal biomasses under both mesophilic $\left(35^{\circ} \mathrm{C}\right)$ and thermophilic $\left(55^{\circ} \mathrm{C}\right)$ conditions, and which was also compared with soluble starch as a substrate for the fermenting bacteria. The fermentation was carried out in triplicate using $150 \mathrm{~mL}$ serum bottles with a working volume of $100 \mathrm{~mL}$. The volume ratio of algae biomass to fermenting bacteria $(\mathrm{AB} / \mathrm{FB})$ ranged from 0 (fermenting bacteria alone) to 1.0 , and $50 \mathrm{~mL}$ fermenting bacteria (dry biomass $=3.4 \mathrm{~g} \mathrm{~L}^{-1}$ ) was used for each of the experimental variations. The headspace of each bottle was flushed with $\mathrm{N}_{2}$ for 15 min to provide an anaerobic environment and then sealed tightly using a butyl rubber stopper and an aluminum crimp. The bottles were placed in a water bath (SH-502S, Seyoung Scientific) kept at a temperature of 35 or $55^{\circ} \mathrm{C}$, and gas/liquid samples were periodically collected from the bottles for measurement of SMP throughout the 23 day fermentation period.

\section{Analytical procedures}

The non-sonicated and sonicated algal cells were primarily-fixed using $4 \%$ glutaraldehyde for $2 \mathrm{~h}$, secondarily-fixed using $1 \% \mathrm{OsO}_{4}$ for $1 \mathrm{~h}$, and rinsed with $0.1 \mathrm{M}$ cacodylate buffer ( $\mathrm{pH}$ 7.4). The resulting samples were then dehydrated with different concentrations of ethanol, sputter-coated with Au-Pd immediately, and examined with a Low-Vacuum Scanning Electron Microscope (LV-SEM, S-3500 N, Hitachi). An ELS-8000 Electrophoretic Light Scattering Spectrophotometer (Ostuka, Japan) was used to determine zeta potential of microalgal cell. Estimation of microalga cell surface hydrophobicity was also performed with the microbial adhesion to hydrocarbon (MATH) test [41].

The concentrations of carbohydrates were determined using an ICS-5000 bio-liquid chromatography (Dionex, USA) with CarboPac PA1 column [42]. The volatile fatty acids (VFAs) were analyzed by a GC-8A Gas Chromatography (Shimadzu, Japan) equipped with a flame ionization detector (FID) and a glass column packed with $10 \%$ Reoplex 400 . Ethanol was analyzed by a DS 6200 Gas Chromatography (Do-Nam Ins., Korea) equipped with a FID and a DB-624 column (Agilent, USA). Hydrogen was measured using a gas chromatograph (Shimadzu GC-14, Japan) equipped with a thermal conductivity detector and a molecular sieve 5A. The concentrations of total and volatile suspended solids were determined using the Standard Methods [43]. The $\mathrm{pH}$ was also measured by a pH meter (Orion 290A).

\section{Abbreviations \\ SMP: Soluble Metabolite Product; VFA: Volatile Fatty Acid; $H_{\max }$ : Maximum Hydrogen Production; $R_{\text {max }}$ : Hydrogen production rate; HPB: Hydrogen Producing Bacteria; SEM: Scanning Electron Microscope.}

\section{Competing interests}

The authors declare that they have no competing interests.

\section{Authors' contributions}

$B H J, J A C, H C K, J H H$ and RAA designed and performed research; $B H J, J A C$, $H C K, J H H, B A D, J M R$, JRK, and RAA analyzed data; and BHJ, JAC, HCK, JHH, $B A D, J M R, R A A$ and JRK wrote the manuscript. All authors reviewed and approved the final manuscript.

\section{Acknowledgements}

This work was supported by the Senior Researchers (National Research Foundation of Korea, 2010-0026904) and the Brain Korea-21 (BK-21) programs of the Korea Ministry of Education, Science, and Technology, and the Eco-Innovation project (Global-Top project, 2012001090001) of the Korea Ministry of Environment. The Korean Basic Science Institute (Chuncheon) is acknowledged for the SEM analysis.

\section{Author details}

${ }^{1}$ Department of Environmental Engineering, Yonsei University, Wonju, Gangwon-do 220-710, South Korea. ${ }^{2}$ Department of Environmental Biotechnology City of Scientific Research and Technology Applications, New Borg El Arab City, Alexandria 21934, Egypt. ${ }^{3}$ Department of Civil and Environmental Engineering, Pennsylvania State University, 212 Sackett Building, University Park, PA 16802, USA. ${ }^{4}$ School of Chemical and Biomolecular Engineering, Pusan National University, Busan 609-735, South Korea. ${ }^{5}$ Current address: Research Institute for Sustainable Environments, Ilshin Environmental Engineering Co., Ltd., Reclean Building 3rd Fl., 692-2 Jangji-dongSongpa-gu, Seoul 138-871, South Korea.

Received: 22 August 2012 Accepted: 12 March 2013

Published: 18 March 2013

\section{References}

1. Lü J, Sheahan C, Fu P: Metabolic engineering of algae for fourth generation biofuels production. Energy Environ Sci 2011, 4:2451-2466.

2. John RP, Anisha GS, Nampoothiri KM, Pandey A: Micro and macroalgal biomass: a renewable source for bioethanol. Bioresour Technol 2011, 102:186-193.

3. Chisti Y: Biodiesel from microalgae. Biotech Adv 2007, 3:294-306.

4. Choi JA, Hwang JH, Dempsey BA, Abou-Shanab RAl, Min B, Song H, Lee DS, Kim JR, Cho Y, Hong S, Jeon BH: Enhancement of fermentative bioenergy (ethanol/hydrogen) production using ultrasonication of Scenedesmus 
obliquus YSW15 cultivated in swine wastewater effluent. Energy Environ Sci 2011, 4:3513-3520.

5. Lee JY, Yoo C, Jun SY, Ahn CY, Oh HM: Comparison of several methods for effective lipid extraction from microalgae. Bioresour Technol 2010, 101:S75-S77.

6. Prabakaran P, Ravindran AD: A comparative study on effective cell disruption methods for lipid extraction from microalgae. Let Appl Microbiol 2011, 53:150-154

7. González-Fernández C, Sialve B, Bernet N, Steyer JP: Comparison of ultrasound and thermal pretreatment of Scenedesmus biomass on methane production. Bioresour Technol 2012, 110:610-616.

8. Tiehm A, Nickel K, Zellhorn M, Neis U: Ultrasonic waste activated sludge disintegration for improving anaerobic stabilization. Water Res 2001, 35:2003-2009.

9. Mason TJ: Industrial sonochemistry: potential and practicality. Ultrasonics 1992, 30:192-196.

10. Mason T, Paniwnyk L, Lorimer J: The uses of ultrasound in food technology. Ultrason Sonochem 1996, 3:S253-S260.

11. Somaglino L, Bouchoux G, Mestas J, Lafon C: Validation of an acoustic cavitation dose with hydroxyl radical production generated by inertial cavitation in pulsed mode: application to in vitro drug release from liposomes. Ultrason Sonochem 2011, 18:577-588.

12. Zakrzewsk ME, Bogel-yukasik E, Bogel-yukasik R: Solubility of carbohydrates in ionic liquids. Energy Fuel 2010, 24:737-745.

13. Becker EW: Micro-algae as a source of protein. Biotech Adv 2007, 25:207-210.

14. Blumreisinger M, Meindl D, Loos E: Cell wall composition of chlorococcal algae. Phytochem 1983, 22:1603-1604

15. Panneerselvam $\mathrm{K}$, Etchison JR, Freeze HH: Human fibroblasts prefer mannose over glucose as a source of mannose for N-glycosylation. J Biol Chem 1997, 272:23123-23129.

16. Zhang M, Zhang L, Cheung PCK, Ooi VEC: Molecular weight and antitumor activity of the water-soluble polysaccharides isolated by hot water and ultrasonic treatment from the sclerotia and mycelia of Pleurotus tuber-regium. Carbohyd Polym 2004, 56:123-128.

17. Oomen AG, Rompelberg CJM, Bruil MA, Dobbe CJG, Pereboom DPKH, Sips AJAM: Development of an In vitro digestion model for estimating the bioaccessibility of soil contaminants. Arch Environ Contam Toxicol 2003, 44:281-287.

18. Mahdy AM, Elkhatib EA, Fathi NO, Lin ZQ: Use of drinking water treatment residuals in reducing bioavailability of metals in biosolid-amended alkaline soils. Commun Soil Sci Plant Anal 2012, 43:1216-1236.

19. Rossi L, ten Hoorn JWM S, Melnikov SM, Velikov KP: Colloidal phytosterols: synthesis, characterization and bioaccessibility. Soft Matter 2010, 6:928-936.

20. Klitzke S, Lang F: Mobilization of soluble and dispersible lead, arsenic, and antimony in a polluted, organic-rich soil - effects of $\mathrm{pH}$ increase and counterion valency. J Environ Qual 2009, 38:933-939.

21. Elimelech $\mathrm{M}$, Nagai $\mathrm{M}, \mathrm{Ko} \mathrm{CH}$, Ryan J: Relative insignificance of mineral grain zeta potential to colloid transport in geochemically heterogeneous porous media. Environ Sci Technol 2000, 34:2143-2148,

22. Chen D, He Z, Weavers LK, Chin YP, Walker H, Hatcher PG: Sonochemical reactions of dissolved organic matter. Res Chem Intermed 2004, 30:735-753.

23. Schechter DS, Singer PC: Formation of aldehydes during ozonation. Ozone Sci Eng 1995, 17:53-69.

24. Volk C, Bell MK, Ibrahim E, Verges D, Amy G, Allier ML: Impact of enhanced and optimized coagulation on removal of organic matter and its biodegradable fraction in drinking water. Water Res 2000, 34:3247-3257.

25. Bosma TP, Middeldorp PJM, Schraa G, Zehnder AJB: Mass transfer limitation of biotransformation:quantifying bioavailability. Environ Sci Technol 1997, 31:248-252.

26. Chin YP, Aiken G, O'Loughlin E: Molecular weight, polydispersity, and spectroscopic properties of aquatic humic substances. Environ Sci Technol 1994, 28:1853-1858.

27. Yin $X$, Han $P, L u X$, Wang $Y$ : A review on the dewaterability of bio-sludge and ultrasound pretreatment. Ultrason Sonochem 2004, 11:337-348.

28. Nandi R, Sengupta S: Microbial production of hydrogen: an overview. Crit Rev Microbiol 1998, 24:61-84.
29. Zhang $Y$, Liu G, Shen J: Hydrogen production in batch culture of mixed bacteria with sucrose under different iron concentrations. Int J Hydrogen Energy 2005, 30:855-860.

30. Lin CY, Chen HP: Sulfate effect on fermentative hydrogen production using anaerobic mixed microflora. Int J Hydrogen Energy 2006, 31:953-960.

31. Hawkes FR, Dinsdale R, Hawkes DL, Hussy I: Sustainable fermentative hydrogen production: challenges for process optimization. Int $\mathrm{J}$ Hydrogen Energy 2002, 27:1339-1347.

32. Li YF, Ren NQ, Chen Y, Zheng GX: Ecological mechanism of fermentative hydrogen production by bacteria. Int J Hydrogen Energy 2007, 32:755-760.

33. Levin DB, Islam R, Cicek N, Sparling R: Hydrogen production by Clostridium thermocellum 27405 from cellulosic biomass substrates. Int J Hydrogen Energy 2006, 31:1496-1503.

34. Lee KS, Lin PJ, Chang JS: Temperature effects on biohydrogen production in a granular sludge bed induced by activated carbon carriers. Int $J$ Hydrogen Energy 2006, 31:465-472.

35. Valdez-Vazquez I, Ríos-Leal E, Esparza-García F, Cecchi F, Poggi-Varaldo HM: Semi-continuous solid substrate anaerobic reactors for $\mathrm{H}_{2}$ production from organic waste: mesophilic versus thermophilic regime. Int J Hydrogen Energy 2005, 30:1383-1391.

36. Abou-Shanab RAl, Hwang JH, Cho Y, Min B, Jeon BH: Characterization of microalgal species isolated from fresh water bodies as a potential source for biodiesel production. Appl Energy 2011, 88:3300-3306.

37. Bischoff HW, Bold HC: in Phycological Sudies IV. Univ Texas Publ 1963, 6318:1-95.

38. Shirgaonkar IZ, Pandit AB: Sonophotochemical destruction of aqueous solution of 2,4,6-trichlorophenol. Utrason Sonochem 1998, 5:53-61.

39. Joseph CG, Puma GL, Bono A, Krishnaiah D: Sonophotocatalysis in advanced oxidation process: a short review. Utrason Sonochem 2009, 16:583-589.

40. Hwang JH, Choi JA, Abou-Shanab RAl, Bhatnagar A, Min B, Song H, Kumar E, Choi J, Lee ES, Kim YJ, Um S, Lee DS, Jeon BH: Effect of pH and sulfate concentration on hydrogen production using anaerobic mixed microflora. Int J Hydrogen Energy 2009, 34:9702-9710.

41. Rosenberg M, Gutnick D, Rosenberg E: Adherence of bacteria to hydrocarbons: a simple method for measuring cell-surface hydrophobicity. FEMS Microbiol Lett 1980, 9:29-33.

42. Ajisaka K, Fujimoto H, Miyasato M: An a-L-fucosidase from Penicillium multicolor as a candidate enzyme for the synthesis of a $(1 \rightarrow 3)$-linked fucosyl oligosaccharides by transglycosylation. Carbohydr Res 1998, 309:125-129.

43. APHA, American Public Health Association: Methods for biomass production. In Standard methods for the examination of water and wastewater. Baltimore (MD, USA): 1998.

doi:10.1186/1754-6834-6-37

Cite this article as: Jeon et al:: Ultrasonic disintegration of microalgal biomass and consequent improvement of bioaccessibility/bioavailability in microbial fermentation. Biotechnology for Biofuels 2013 6:37.

\section{Submit your next manuscript to BioMed Central and take full advantage of:}

- Convenient online submission

- Thorough peer review

- No space constraints or color figure charges

- Immediate publication on acceptance

- Inclusion in PubMed, CAS, Scopus and Google Scholar

- Research which is freely available for redistribution 